\title{
MENINGKATKAN AKTIVITAS DAN PRESTASI BELAJAR SISWA DALAM PEMBELAJARAN BANGUN RUANG SISI DATAR MELALUI PENERAPAN MODEL PEMBELAJARAN KOOPERATIF TIPE TGT PADA SISWA KELAS VIII-I SMP DWIJENDRA DENPASAR TAHUN AJARAN 2011/2012
}

\author{
Ni Nyoman Maheni, I Gusti Ngurah Nila Putra \\ Program Studi Pendidikan Matematika \\ Fakultas Keguruan dan Ilmu Pendidikan \\ Universitas Mahasaraswati Denpasar
}

\begin{abstract}
This study aimed at improving the activities and achievements of students learning. This research is a Class Action Research which was done in three cycles. Based on the result of data analysis, it shows that the student learning activity score of cycle I until cycle III and category in a row are "14,897", "19,583", and "20,710" with category are "fairly active", "active", and "very active". The result of data analisys of learning achivement, the average score, mastery learning, and absorptive ability of cycle I until cycle III in a row are "7,67", "7,77", and "8,25"; "53,85\%", "71,05\%", and "89,74\%"; and "76,7\%", "77,7\%", and " $82,5 \%$ ". The result of data analisys of implementation of the learning of cycle I until cycle III and category in a row are "79,54\%", "93,175\%" and "100\%" with category are "good", "very good", and "very good". While for result analisys data of student response, achieving very positive category with an average score of responses student "32,13". Thus, the application of cooperative learning type TGT in learning the math flat side geometry can improve the activities and achievements of students learning.
\end{abstract}

Keywords: cooperatif learning type TGT, flat side geometry, learning activities, learning achievement, student response 


\section{PENDAHULUAN}

Undang-Undang Nomor 20 Tahun 2003 tentang Sistem Pendidikan Nasional menyebutkan bahwa pendidikan nasional berfungsi mengembangkan kemampuan dan membentuk watak serta peradaban bangsa yang bermartabat dalam rangka mencerdaskan kehidupan bangsa, bertujuan untuk mengembangkan potensi peserta didik agar menjadi manusia yang beriman dan bertaqwa kepada Tuhan Yang Maha Esa, berakhlak mulia, sehat, berilmu, cakap, kreatif, mandiri, dan menjadi warga Negara yang demokratis serta bertanggung jawab. Maka dari itu dunia pendidikan selalu mendapat perhatian serius dari pemerintah berkaitan dengan tuntutan menghasilkan Sumber Daya Manusia (SDM) yang berkualitas dan berkompeten. Perubahan dan perkembangan merupakan hal yang seharusnya sejalan dengan perubahan budaya kehidupan. Perubahan budaya yang dimaksud adalah suatu upaya perbaikan sistem pendidikan pada semua tingkat yang secara terus menerus dilakukan sebagai tindak lanjut kepentingan masa depan.

Sekolah sebagai lembaga pendidikan formal, membuka kesempatan bagi peserta didik untuk melakukan berbagai kegiatan belajar, dengan berbagai kesempatan belajar, pertumbuhan dan perkembangan peserta didik diarahkan dan didorong ke pencapaian tujuan yang dicita-citakan. Untuk mencapai tujuan tersebut, sekolah menyelenggarakan kegiatan melalui kegiatan belajar mengajar berdasarkan kurikulum yang ditetapkan. Salah satu pembelajaran yang berkembang adalah pembelajaran matematika. Peran guru sangat penting agar tujuan pembelajaran matematika tercapai. Selama ini pembelajaran matematika masih menerapkan pendekatan konvensional yang cenderung berpusat pada guru (teacher centered). Namun yang terjadi, siswa menjad pasif, karena hanya mendengar dan mencatat penjelasan guru yang akan bermuara pada rendahnya prestasi belajar siswa.

Pendekatan konvensional juga diterapkan di SMP Dwijendra Denpasar. Hal ini terungkap ketika peneliti mengadakan observasi saat guru mengajar dan diperkuat dengan wawancara dengan guru matematika kelas VIII-I SMP Dwijendra Denpasar.
Pada intinya permasalahan yang ditemui yaitu aktivitas siswa kurang yang berdampak siswa enggan untuk bertanya, siswa terkesan pasif, guru tidak pernah memberikan motivasi belajar kepada siswa, komunikasi yang terjadi satu arah, siswa kurang diberikan kesempatan untuk memecahkan masalah, dan siswa bersifat individual.

Penerapan model pembelajaran kooperatif tipe TGT dapat membantu guru untuk menarik minat siswa untuk belajar serta dapat meningkatkan aktivitas dan prestasi belajar siswa yang memungkinkan siswa berperan aktif dalam kegiatan pembelajaran, serta dapat menciptakan interaksi antar siswa yang mengandalkan kerja sama dan melalui kelompok kecil untuk menyelesaikan tugastugasnya. Model pembelajaran kooperatif tipe TGT dirancang khusus untuk mengajak siswa berperan aktif dalam pembelajaran. Ciri khusus yang dimiliki dari model pembelajaran kooperatif tipe TGT yaitu belajar kelompok, permainan/turnamen akademik, pemberian penghargaan, dan pemindahan (bumping). Melalui permainan/turnamen akademik, siswa diharapkan mampu bersaing atau berkompetisi untuk memperoleh skor terbaik untuk kelompoknya, selanjutnya dibagi kelompok yang memperoleh skor terbaik akan diberikan penghargaan.

Berdasarkan uraian di atas, peneliti tertarik untuk mengadakan penelitian yang berjudul "Meningkatkan Aktivitas dan Prestasi Belajar Siswa dalam Pembeajaran Bangun Ruang Sisi Datar melalui Penerapan Model Pembelajaran Kooperatif Tipe TGT pada Siswa Kelas VIII-I SMP Dwijendra Denpasar Tahun Pelajaran 2011/2012"

\section{METODE PENELITIAN}

Penelitian ini menggunakan pendekatan kualitatif, dimana pendekatan ini adalah penelitian yang bermaksud untuk memahami fenomena tentang apa yang dialami oleh subyek penelitian, misalnya perilaku, persepsi, motivasi dan tindakan secara holistik. Kemudian diolah dengan cara deskripsi dalam bentuk kata-kata dan bahasa, pada suatu konteks khusus yang alamiah dan dengan memanfaatkan berbagai metode ilmiah (Moleong, 2011:6). 
Jenis penelitian yang dilaksanakan adalah Penelitian Tindakan Kelas (PTK). Suandhi (2006:3) menyatakan penelitian tindakan kelas dapat didefinisikan sebagai suatu bentuk penelitian reflektif dengan melakukan tindakan-tindakan tertentu agar dapat memperbaiki dan atau meningkatkan mutu praktek-praktek pembelajaran di kelas secara lebih profesional. Desain PTK yang digunakan dalam penelitian ini adalah desain PTK model Kemmis dan Mc. Taggart yang mengandung tiga tahap pada setiap siklusnya. Ketiga komponen tersebut adalah: (a) perencanaan, yaitu: rencana tindakan yang akan dilakukan untuk memperbaiki, meningkatkan, atau perubahan perilaku dan sikap sebagai solusinya, (b) tindakan dan observasi, yaitu: apa yang dilakukan oleh guru atau peneliti sebagai upaya perbaikan, peningkatan, atau perubahan yang diinginkan dengan mengamati hasil atau dampak dari tindakan yang dilakukan dan dikenakan terhadap siswa, (c) refleksi, yaitu: peneliti mengkaji, melihat dan mempertimbangkan atas hasil atau dampak dari tindakan tersebut dari berbagai segi.

Penelitian ini direncanakan dalam 3 siklus. Penelitian ini dilaksanakan di SMP Dwijendra Denpasar yang beralamat di Jalan Kamboja No. 17, Desa Dangin puri, Kecamatan Denpasar Barat, Kota Denpasar pada tahun pelajaran 2011/2012 dengan subyek penelitian siswa kelas VIII-B yang terdiri dari 39 orang.

Data yang dikumpulkan dalam penelitian ini meliputi data aktivitas belajar siswa, data prestasi belajar siswa, data keterlaksanaan pembelajaran, data tanggapan siswa dan catatan lapangan. Data aktivitas belajar siswa dikumpulkan dengan teknik observasi berupa instrumen lembar observasi aktivitas belajar. Data prestasi belajar siswa dikumpulkan dengan teknik tes. Tes yang diberikan berupa tes objektif dan uraian. Data keterlaksanaan pembelajaran dikumpulkan dengan menggunakan teknik observasi yang dilakukan selama kegiatan pembelajaran berlangsung pada setiap pertemuan. Data tanggapan siswa terhadap penerapan model pembelajaran kooperatif tipe TGT dikumpulkan dengan metode korespondensi dengan instrumen berupa kuisioner atau angket. Sedangkan catatan lapangan dibuat oleh peneliti dan rekan sejawat dengan melakukan pencatatan terhadap pelaksanaan pembelajaran.

Data aktivitas belajar siswa dianalisis dengan menggunakan analisis statistik deskriptif komparatif, dan digolongkan berdasarkan kriteria dari Nurkencana dan Sunartana (1992:100). Analisis hasil belajar siswa dilakukan berdasarkan atas rata-rata skor prestasi belajar siswa, ketuntasan belajar dan daya serap (Nurkencana dan Sunartana, 1992:173). Hasil perhitungan rata-rata skor prestasi belajar siswa $(\overline{\mathrm{X}})$, ketuntasan belajar $(\mathrm{KB})$ dan daya serap (DS) selanjutnya dikomparasikan dengan standar acuan yang ditetapkan Depdikbud, bahwa proses pembelajaran telah optimal apabila rata-rata skor prestasi elajar siswa $(\overline{\mathrm{X}})$, daya serap (DS), dan ketuntasan belajar (KB) masing-masing minimal 6,50\%, 65\% dan 85\% (Depdikbud, 1994:34). Data keterlaksanaan pembelajaran dianalisis dengan menggunakan analisis statistik deskriptif komparatif, yaitu dengan menentukan persentasi keterlaksanaan pembelajaran (KP), dan selanjutnya dikomparasikan ke dalam konversi skor dengan skala lima. Data tanggapan siswa terhadap penerapan model pembelajaran kooperatif tipe TGT dalam pembelajaran bangun ruang sisi datar dianalisis secara statistik deskriptif komparatif.

\section{HASIL PENELITIAN DAN PEMBAHASAN}

\section{Hasil Penelitian}

Berdasarkan hasil analisis data aktivitas belajar siswa maka diperoleh hasil pengolahan data mengenai aktivitas belajar siswa dalam Tabel 01 .

Tabel 1. Hasil Analisis Data Aktivitas Belajar Siswa

\begin{tabular}{|c|c|c|c|}
\hline Siklus & Pertemuan & $\begin{array}{c}\text { Mean Skor } \\
\text { Aktivitas } \\
\text { Belajar }\end{array}$ & Predikat \\
\hline \multirow{3}{*}{ I } & 1 & 12,231 & Cukup Aktif \\
\hline & 2 & 17,564 & Aktif \\
\hline & Rata-rata & 14,897 & Cukup Aktif \\
\hline \multirow{3}{*}{ II } & 4 & 18,167 & Aktif \\
\hline & 5 & 21,00 & Sangat Aktif \\
\hline & Rata-rata & 19,583 & Sangat Aktif \\
\hline \multirow{3}{*}{ III } & 7 & 20,052 & Sangat Aktif \\
\hline & 8 & 21,368 & Sangat Aktif \\
\hline & Rata-rata & 20,710 & Sangat Aktif \\
\hline
\end{tabular}


Selanjutnya, hasil analisis data prestasi belajar siswa dan persentase keterlaksanaan pembelajaran dapat dilihat pada Tabel 02 dan Tabel 03 berikut.

Tabel 02. Hasil Analisis Data Prestasi Belajar Siswa

\begin{tabular}{cccc} 
Siklus & $\begin{array}{c}\text { Rata-rata } \\
\text { Nilai Siswa } \\
(\overline{8})\end{array}$ & $\begin{array}{c}\text { Ketuntasan } \\
\text { Belajar (KB) }\end{array}$ & $\begin{array}{c}\text { Daya } \\
\text { Serap } \\
\text { (DS) }\end{array}$ \\
\hline I & 7,67 & $53,85 \%$ & $76,7 \%$ \\
\hline II & 7,77 & $71,05 \%$ & $77,7 \%$ \\
\hline III & 8,25 & $89,74 \%$ & $82,5 \%$ \\
\hline
\end{tabular}

Tabel 03. Hasil Analisis Data Keterlaksanaan Pembelajaran

\begin{tabular}{rccc}
\hline Siklus & Pertemuan & $\begin{array}{c}\text { Keterlaksanaan } \\
\text { P. }(\%)\end{array}$ & Predikat \\
\hline \multirow{3}{*}{ I } & 1 & 77,27 & Cukup baik \\
\cline { 2 - 4 } & 2 & 81,81 & Baik \\
\cline { 2 - 4 } & Rata-rata & 79,54 & Cukup baik \\
\hline \multirow{3}{*}{ II } & 4 & 90,9 & Sangat baik \\
\cline { 2 - 4 } & 5 & 95,45 & Sangat baik \\
\cline { 2 - 4 } & Rata-rata & 93,175 & Sangat baik \\
\cline { 2 - 4 } & 7 & 100 & Sangat baik \\
\hline \multirow{2}{*}{ III } & 8 & 100 & Sangat baik \\
\cline { 2 - 4 } & Rata-rata & 100 & Sangat baik \\
\cline { 2 - 4 } & Rata & &
\end{tabular}

Berdasarkan hasil analisis data tanggapan siswa, maka diperoleh skor rata-rata tanggapan siswa pada penerapan model pembelajaran kooperatif tipe TGT yaitu 32, 13 dengan pedikat "sangat positif".

\section{Pembahasan}

Berdasarkan hasil observasi awal di kelas VIII-I SMP Dwijendra Denpasar tahun ajaran 2011/2012 diperoleh informasi tentang aktivitas dan prestasi belajar siswa pada pembelajaran matematika belum mencapai hasil yang optimal. Hal ini ditunjukkan kurang adanya semangat dan motivasi dalam proses pembelajaran serta masih rendahnya nilai ulangan harian matematika siswa yang belum mencapai kriteria keberhasilan minimal yaitu rata-rata skor prestasi belajar siswa $(\bar{X}) \geq 6,5$, ketuntasan belajar $(\mathrm{KB}) \geq 85 \%$, dan daya serap (DS) $\geq 65 \%$.

Penyebab dari rendahnya aktivitas dan prestasi belajar siswa dalam pembelajaran matematika, antara lain: (a) proses pembelajaran yang cenderung berpusat pada guru dimana guru dalam menjelaskan materi pelajaran menggunakan metode ceramah, (b) siswa kurang bersemangat dalam mengerjakan tugas yang diberikan oleh guru, karena guru kurang memperhatikan perkembangan kognitif siswa, dan (c) guru tidak pernah memberikan penghargaan untuk siswa sebagai motivasi belajar siswa.

Berdasarkan hasil analisis data pada siklus I diperoleh rata-rata skor aktivitas belajar siswa $(\overline{\mathrm{A}})$ 14,897 dengan predikat "cukup aktif", rata-rata skor prestasi belajar siswa $\left({ }^{\bar{X}}\right) 7,67$, ketuntasan belajar (KB) $53,85 \%$, dan daya serap (DS) 76,7\%. Dilihat dari ${ }^{\bar{A}}, \overline{\mathrm{X}}, \mathrm{KB}$ dan DS, pembelajaran pada siklus I belum memenuhi kriteria minimal yang ditetapkan, yaitu $\overline{\mathrm{A}}_{\text {belum mencapai predikat "aktif", }} \overline{\mathrm{X}}_{\geq 6,5}$, $\mathrm{KB} \geq 85 \%$, dan $\mathrm{DS} \geq 65 \%$. Belum tercapainya kriteria minimal yang ditetapkan diduga disebabkan oleh: (a) siswa belum terbiasa dengan model pembelajaran kooperatif tipr TGT, (b) ada beberapa siswa yang bermain saat guru menjelaskan materi, (c) ada beberapa siswa yang kurang aktif dalam kelompok, (d) pendekatan guru dan arahan kepada siswa saat mengerjakan LKS masih kurang intensif, (e) siswa tidak memperhatikan waktu yang tersedia dengan baik saat mengerjakan LKS atau pada saat turnamen akademik, dan (f) siswa yang pandai mendominasi dalam kelompok bekerja dan belajar. Di samping itu, belum optimal proses pembelajaran pada siklus I juga diduga disebabkan oleh belum maksimalnya penerapan model pembelajaran kooperatif tipe TGT. Dimana, hal ini ditunjukkan oleh rata-rata persentase keterlaksanaan pembelajaran $(\overline{\mathrm{KP}}$ ) baru mencapai $79,54 \%$ dengan predikat "cukup baik" dari predikat minimal yang diharapkan yaitu predikat "sangat baik".

Selanjutnya, sebelum melaksanakan siklus II, perlu diadakan refleksi sebagai upaya perbaikan agar kendala-kendala yang terjadi pada sikus I tidak akan muncul lagi pada siklus II. Adapun langkahlangkah perbaikan dimaksud, meliputi: (a) guru menjelaskan kembali langkah-langkah model pembelajaran kooperatif tipe TGT, (b) memberikan teguran dan pertanyaan secara spontan kepada siswa yang bermain untuk memfokuskan perhatian siswa, (c) membimbing siswa yang kurang aktif dalam berdiskusi dan menanyakan permasalahan yang 
sedang dihadapi dalam melakukan diskusi, (d) guru lebih intensif dalam memberikan bimbingan dan arahan pada tiap kelompok, (e) guru mengingatkan waktu yang tersedia kepada siswa, dan (f) guru mengingatkan siswa aturan-aturan dalam kelompok bekerja dan belajar.

Berdasarkan analisis data aktivitas belajar pada siklus II diperoleh $\overline{\mathrm{A}}_{19,583}$ dengan predikat "sangat aktif". Hal ini menunjukkan aktivitas belajar siswa telah mencapai kriteria minimal. Jika dibandingkan dengan $\overline{\mathrm{A}}_{\text {pada siklus I telah terjadi }}$ peningkatan sebesar $31,45 \%$. Sementara, berdasarkan hasil analisis data prestasi belajar siswa pada siklus II diperoleh ${ }^{\overline{\mathrm{X}}}, \mathrm{KB}$ dan DS berturutturut 7,77; 71,05\%; dan 77,7\%. Apabila dibandingkan prestasi belajar siswa pada siklus I, nampak telah terjadi peningkatan prestasi belajar $\overline{\mathrm{X}}$ sebesar 1,30\%, , KB sebesar 31,94\%, dan DS sebesar 1,30\%. Meskipun telah terjadi peningkatan prestasi belajar siswa dari siklus I ke siklus II, namun belum tercapainya kriteria minimal untuk KB. Dilihat dari proses penerapan model

pembelajaran kooperatif tipe TGT, $\overline{\mathrm{KP}}$ sudah mencapai kriteria minimal yaitu 93,175\% dengan predikat "sangat baik". Berdasarkan hasil observasi diperoleh bahwa belum optimalnya proses pembelajaran pada siklus II diduga disebabkan oleh: (a) siswa lebih memperhatikan temannya di kelompok lain saat melakukan turnamen akademik, dan (b) perbedaan pendapat dalam kelompok tidak didiskusikan secara langsung pada kelompok dan bertanya pada guru.

Selanjutnya, berdasarkan hasil observasi dilakukan refleksi sebagai upaya perbaikan agar kendala-kendala yang terjadi pada sikus II tidak akan muncul lagi pada siklus III. Adapun langkahlangkah perbaikan dimaksud, meliputi: (a) menegur siswa secara langsung agar lebih memperhatikan kegiatan turnamen di meja turnamennya sendiri, dan (b) guru lebih memperhatikan kerja siswa dalam kelompok dan memberikan bimbingan sesuai pembelajaran kooperatif.

Berdasarkan hasil yang diperoleh dari siklus I dan siklus II, nampak terlihat bahwa aktivitas belajar siswa terjadi peningkatan sesuai dengan kriteria minimal yang ditetapkan, prestasi belajar siswa pada $\overline{\mathrm{X}}$ dan DS mengalami peningkatan sesuai dengan kriteria minimal yang ditetapkan, serta keterlaksanaan pembelajaran juga terjadi peningkatan sesuai dengan kriteria minimal yang ditetapkan. Namun, pada KB belum mencapai kriteria minimal yang ditetapkan, maka dilaksanakan siklus III sebagai upaya untuk meningkatkan KB agar mencapai kriteria minimal yang ditetapkan.

Berdasarkan hasil analisis aktivitas siswa, prestasi belajar siswa, dan keterlaksanaan pembelajaran, diperoleh data $\overline{\mathrm{A}}=20,710 ;{ }^{\overline{\mathrm{X}}}=8,25$; $\mathrm{KB}=89,74 \%$; DS $=82,5 \%$; dan $\mathrm{KP}=100 \%$. Dari pelaksanaan tindakan pada siklus III terlihat bahwa terjadi peningkatan dan mencapai kriteria minimal yang ditetapkan. Kemudian, pada akhir pembelajaran pada siklus III dilaksanakan pengisian angket sebagai lembar tanggapan siswa dan memperoleh rata-rata skor sebesar 32,13 dengan predikat "sangat positif". Secara keseluruhan siswa merasa senang dengan penerapan model pembelajaran kooperatif tipe TGT serta pemberian penghargaan menjadi salah satu motivasi siswa dalam belajar. Hasil observasi pada siklus III menunjukkan bahwa: (a) masih adanya siswa yang memperhatikan temannya di kelompok lain saat melakukan turnamen akademik dan (b) siswa merasa senang dengan penerapan model pembelajaran kooperatif tipe TGT. Berdasarkan hasil observasi tersebut menunjukkan bahwa perbaikan yang dilaksanakan sudah berhasil. Ini berarti, pembelajaran dikatakan optimal apabila aktivitas belajar siswa minimal mencapai predikat "aktif", rata-rata nilai prestasi belajar siswa $(\bar{X}) \geq$ 6,5 , ketuntasan belajar (KB) $\geq 85 \%$, daya serap (DS) $\geq 65 \%$, keterlaksanaan pembelajaran mencapai predikat "sangat baik", dan tanggapan siswa mencapai predikat "positif". Dari hasil analisis data yang diperoleh pada siklus III, maka pembelajaran pada siklus III telah optimal karena telah memenuhi semua kriteria keberhasihan minimal yang telah ditetapkan. Oleh karena pembelajaran telah optimal dan hasil yang dicapai pada siklus III ini telah memenuhi kriteria minimal, maka penelitian ini dihentikan sampai pada siklus III. 
Dari uraian di atas, diperoleh bahwa semua kriteria keberhasilan minimal yang telah ditetapkan terpenuhi karena aktivitas dan prestasi belajar siswa kelas VIII-I SMP Dwijendra Denpasar telah mengalami peningkatan dari siklus I, siklus II, dan siklus III dimana aktivitas belajar siswa mencapai predikat "sangat aktif" dan prestasi belajar siswa telah mencapai kriteria keberhasilan minimal yang ditetapkan. Serta keterlaksanaan pembelajaran memperoleh predikat "sangat baik" dan tanggapan siswa terhadap penerapan model pembelajaran kooperatif tipe TGT memperoleh predikat "sangat positif". Hal ini mengindikasikan bahwa pelaksanaan penelitian tindakan kelas yang difokuskan untuk mengetahui apakah terjadi peningkatan aktivitas dan prestasi belajar siswa dalam pembelajaran bangun ruang sisi datar melalui penerapan model pembelajaran kooperatif tipe TGT pada siswa kelas VIII-I SMP Dwijendra Denpasar tahun pelajaran 2011/2012 terjadi peningkatan aktivitas dan prestasi belajar serta penelitian dapat dikategorikan berhasil.

\section{PENUTUP}

Berdasarkan hasil analisis data dan pembahasan pada bab IV, maka dapat disimpulkan sebagai berikut. 1) Terjadi peningkatan aktivitas belajar siswa dalam pembelajaran bangun ruang sisi datar melalui penerapan model pembelajaran kooperatif tipe TGT pada siswa kelas VIII-I SMP Dwijendra Denpasar tahun pelajaran 2011/2012. Hal ini ditunjukkan dengan peningkatan kategori aktivitas belajar siswa dari "cukup aktif" pada siklus I menjadi "sangat aktif" pada siklus II dan siklus III, 2) Terjadi peningkatan prestasi belajar siswa dalam pembelajaran bangun ruang sisi datar melalui penerapan model pembelajaran kooperatif tipe TGT pada siswa kelas VIII-I SMP Dwijendra Denpasar tahun pelajaran 2011/2012. Hal ini ditunjukkan dengan adanya peningkatan rata-rata nilai siswa $(\overline{\mathrm{X}})$, ketuntasan belajar $(\mathrm{KB})$ dan daya serap (DS) berturut-turut dari siklus I ke siklus II dan siklus II ke siklus III sebesar " $1,30 \%$ ", "31,94\%" dan " $1,30 \% "$, dan "6,56\%", " $26,30 \% "$ dan " $6,56 \%$ ", 3) Kegiatan pembelajaran dengan pokok bahasan bangun ruang sisi datar yang dilaksanakan di kelas VIII-I SMP Dwijendra Denpasar tahun pelajaran 2011/2012 telah sesuai dengan langkah-langkah pembelajaran kooperatif tipe TGT dengan kategori "cukup baik" pada siklus I, kategori "sangat baik" pada siklus II, dan tetap mencapai kategori "sangat baik" pada siklus III, 4) Tanggapan siswa terhadap penerapan model pembelajaran kooperatif tipe TGT dalam pembelajaran bangun ruang sisi datar pada siswa kelas VIII-I SMP Dwijendra Denpasar tahun pelajaran 2011/2012 yaitu "sangat positif".

Berdasarkan simpulan di atas, maka saran yang dapat disampaikan sebagai berikut. 1) Kepada guru matematika di SMP Dwijendra Denpasar agar dapat menerapkan model pembelajaran kooperatif tipe TGT sebagai alternatif dalam pemilihan model pembelajaran matematika di SMP serta dapat meningkatkan keterampilan siswa untuk berkooperatif dan berkompetisi, serta dapat meningkatkan prestasi belajar siswa, 2) Kepada Kepala Sekolah khususnya di SMP Dwijendra Denpasar, diharapkan hasil penelitian ini dapat dijadikan bahan pertimbangan dalam penyempurnaan kurikulum sebagai salah satu model pembelajaran yang dapat meningkatkan prestasi belajar siswa, 3) Kepada peneliti lain yang berminat dengan penelitian ini diharapkan untuk mengadakan penelitian lebih lanjut dengan subjek penelitian dan pokok bahasan yang berbeda sehingga meningkatkan aktivitas dan prestasi belajar siswa dan semoga hasil penelitian ini dapat dijadikan sebagai informasi atau masukan guna mendapatkan hasil yang lebih baik.

\section{DAFTAR PUSTAKA}

Moleong, Lexy J. (2011). Metodelogi Penelitian Kualitatif. Bandung: PT. Remaja Rosdakarya. Nurkencana, W. dan Sunartana. (1992). Evaluasi Hasil Belajar. Surabaya: Usaha Nasional.

Suandhi, I. W. (2006). Penelitian Tindakan Kelas (diktat tidak diterbitkan). Denpasar: Universitas Mahasaraswati Denpasar. 
